\title{
RESISTANCE, RESILIENCE, AND RESURGENCE: TRACING THE RS IN INDIGENOUS LITERARY STUDIES
}

\author{
RESISTÊNCIA, RESLLIÊNCIA E RESSURGÊNCIA: PERSEGUINDO OS ERRES NOS ESTUDOS LITERARIOS \\ INDÍGENAS
}

\begin{abstract}
This text explores theoretical terms-resistance, resurgence, resilience, respect, reciprocity-in contemporary Indigenous literary studies in North America while pointing out that the many of the powerful stories by Indigenous authors that center on the importance of respect, reciprocal relationships, responsibility, and reverence might serve as maps for us all through some of the thorny issues in today's world.
\end{abstract}

Keywords: Indigenous. Literature. Resistance. Resurgence. Resilience.

\section{RESUMO}

O presente texto explora teoricamente termos tais como resistência, ressurgência, resiliência, respeito, reciprocidade no âmbito dos estudos literários indígenas na contemporaneidade, especificamente na América do Norte. Ao longo da discussão, apontamos que muitas das fortes estórias criadas por autores indígenas, que se centram na importância do respeito, das relações recíprocas, na responsabilidade e reverência podem servir como mapas que nos guiam por entre tópicos espinhosos do mundo contemporâneo.

Palavras-chave: Literatura. Resistência. Ressurgência. Resiliência.

\section{Roots}

This paper traces its roots to a lecture I gave as an invited speaker at the Terceira Jornada Gênero e Literatura: Vozes indígenas: cultura e resistência at the Universidade Federal de Paraíba, João Pessoa, Brazil. I was honored to be invited to speak at the meeting as all those terms-gender, literature, Indigenous, voices, culture and resistance-seem to mark out my work as a feminist scholar of life narratives in the Americas. ${ }^{1}$ As a settler scholar now working at the University of Alberta, a university located on Treaty Six territory, on lands that have long been a gathering place for diverse Indigenous peoples including the Cree, Blackfoot, Métis,

1 See, for example, my 2009 book Acts of Narrative Resistance: Women's Autobiographical Writings in the Americas.

Laura Jean Beard

University of Alberta, Canada. Email: lbeard@ualberta.ca 
Nakota Sioux, Iroquois, Dene, Ojibway/ Saulteaux/Anishinaabe, Inuit, and others, I have responsibilities to listen and to learn, to figure out what it means to live in responsible relations on those lands. Part of how I do that is through reading and learning from Indigenous literatures, authors, and critics.

\section{Resistance, resilience, and resurgence}

I start with Cherokee scholar and writer Daniel Heath Justice's wonderful 2018 book Why Indigenous Literatures Matter, which itself starts with a preface entitled, "Notes for the Long Rebellion." The book is about stories and why stories matter in and to Indigenous communities, with the title of the preface itself evoking resistance. In writing about how and why stories matter, Justice puts his arguments into the broader historical, social, and political context of colonialism in the Americas, reminding us all that "colonialism is as much about the symbolic diminishment of Indigenous peoples as the displacement of our physical presence" (xviii). Without Indigenous peoples, there are no Indigenous stories, so resistance can be a powerful motivation for writing or telling stories. Justice includes a potent piece from Anishinaabe poet and storyteller Marie Annharte Baker to make his point:

I have my mother to thank for her spirit of resistance. I remember my mother and others talking about running away from residential school. I have talked to others about inheriting the anger and rage of our mothers. Her generation was silenced. I cannot but consider a need to document and bear witness to the treatment of First Nations women which comes from what I see as the blood price paid for any of our cultural productions to have survived the onslaught of 500 years of domination and attempts to wipe out our spirituality, our land base and oral literature/language. (quoted in Justice 207)

When we read Indigenous literature, when we listen to Indigenous stories and voices, we are honoring and recognizing the sacrifices of those who came before and the Indigenous presence of those who are here now, in the Indigenous present.

Resistance has been a concept widely employed by and about Indigenous writers, critics, and activists. Métis scholar Kim Anderson entitles the third section of her 2000 book, A Recognition of Being: Reconstructing Native Womanhood, "Resist," with chapters entitled "Foundations of Resistance," "Acts of Resistance," and "Attitudes of Resistance." In setting out that section, she notes that "Aboriginal women have had to become practised at resistance. Through collective resistance, Native women have worked hard to protect their cultures and sustain the social and political fabric of their nations. On a personal level, Native women have had to defend their identities" (115). Anderson's work underscores how "[b]y resisting 
negative definitions of their personal being, Native women question the imbalance and injustice that is encouraged by a colonial patriarchal society" (115).

This form of resistance outlined by Anderson is one that plays out, of course, in literary works by Indigenous women. As Stó:lō author Lee Maracle, a traditional educator, orator, activist, actor and author, reminds us in Memory Serves: Oratories, a beautiful book which contains pieces that Maracle originally presented orally over the years, Indigenous people know that "we have the knowledge that can restore our human journey to the good life. We train our children to remember this knowledge. We train them with story" (11). Stories matter; Indigenous literatures matter, and they matter as acts of resistance, as models for showing and inspiring resistance and as works that commemorate resistance.

Lee Maracle's 2014 novel, Celia's Song, for example, a novel I have written about elsewhere, ${ }^{2}$ tells the story of the title character, Celia, working with others in her family and community to bring healing and balance back to her Nuu'chalnulth community, a community that continues to suffer the continuing reverberations of the legacies of the Canadian Indian residential school system, including the neglect of ceremony. The story is, in many ways, shattering, but as Mink, a narrator in the text, reminds us:

This story deserves to be told; all stories do. Even the waves of the sea tell a story that deserves to be read. The stories that really need to be told are those that shake the very soul of you. (Maracle, Celia's Song 6-7, italics in the original)

Throughout the narrative, we see the members of Celia's community coming together, taking responsibility, looking to the past and to the future, working together within the cultural context of Stó:lō traditions and ceremonies. Indeed, when the characters begin to talk about ceremony and witnesses, Mink rejoices: "Now they're getting somewhere. Ceremony, witnesses: the Stó:lō way of doing business" (Maracle, Celia's Song 73 , italics in the original).

The resistance and resilience of the Indigenous women in the novel are key as they return to the longhouse, to dance, to ceremony. Maracle affirms in Memory Serves, "I have always declined the victim stories. . . . Though I imagine the war, the slavery, the natural disasters and the social implosion that goes with all that, our ceremonies are largely a response to implosion and our stories are about our recovery, not our demise" (Maracle, Memory Serves 88). Celia's Song bears out that claim, telling a story that is shattering but ultimately about recovery, resilience, and the building of a stronger present and presence.

That the story of Celia's Song is shattering but ultimately about building a stronger present is recognized by readers. As Anishinaabekwe scholar Leanne

2 See my 2018 article in Studies in American Indian Literatures. 
Betasamosake Simpson notes in a conversation with Maracle about Celia's Song appearing in Quill \& Quire:

One of the things I noticed when I was reading it was the response of my body and my emotions. When I'm reading a book I usually go in with a critical mind. I think it's because I don't trust the writer. And I feel I really trusted you. ... As an indigenous woman reading your book, I feel that, although it's going to take me to some dark places, and I'm going to have to stand there and witness it, and there's things I'm going to have to face myself - things that have happened in my own life - it's also going to be okay. You're going to take me on this journey and it's going to be okay. (Lee Maracle's Tale)

Maracle takes all her readers on a journey and then leaves them to take up the story. Celia's Song ends with last lines from Mink:

I am done here. This is all I committed to tell. You know what to do with the story now. I skitter up the hill, away from the humans, and under the moon's light I lie down to sleep (Maracle, Celia's Song 269).

Readers are addressed directly by this story. "You know what to do with the story now." We are being asked to take on what Kim Blaeser calls a "response-able way of reading" (64), a way of reading Indigenous narratives is both intellectual and moral. We are asked to learn "our role in story" and then carry "that role into daily life" (64). Stories create responsibilities in us and we have a responsibility to act on the knowledge the story creates in us. Maracle's text focuses on storytelling and witnessing. In doing so, as readers we are challenged to serve as witnesses to what is happening both in the narrative and across Canada and to allow ourselves to become imbricated in the stories, so that we take up the responsibilities of respect and reciprocity in relation to the stories we witness.

The conversation between Maracle and Simpson directly underscores issues of gender and voice in the novel. Simpson tells Maracle that with Celia's Song she trusts "that indigenous women are going to be portrayed not just in a positive way, but an amazing way. And I feel like I've come out of this feeling proud; I've come out feeling powerful; I've come out feeling defiant" (Lee Maracle's Tale). At other points of the interview, Maracle speaks about how the women tell one kind of stories and the men another, an aspect of her culture that also governs her writing. Maracle is a writer secure in her craft, in her own responsibilities to family, to community, and to story.

So while resistance may be a part of what we hear or see when we listen to or read Indigenous stories, I want to resist a reading that focuses solely on the lens of 
resistance. Resistance too often emphasizes reacting to the non-Indigenous world, putting the priority or the power back on the settler colonial side. Contemporary Indigenous authors and critics focus on their own cultures, communities, and traditions rather than keeping the gaze on the colonizers and on the continuing impact of settler colonization. Cree-Métis scholar Deanna Reder emphasizes this point in her 2010 essay "Awina Maga Kiya (Who is it that you really are)?: Cree and Métis Autobiographical Writing," asserting that she does "not rely upon vocabulary like "resistance literature," "testimonio," and "witnessing," coined by autobiography studies, because while these terms are useful for certain conversations, they also reinscribe an identity as colonized and leave us less able to engage with writing that is not overtly "resistant" or political". For Reder, it is important to approach the Cree texts using Cree values and Cree paradigms, and asking questions guided by those Cree beliefs.

Maracle similarly focuses on the Stó:lō way of telling stories; Memory Serves is peppered with remarks about how stories work in her community. To cite just one example:

Stories are tied to history, and serve the direction the communities need to take in the context of human catastrophes. They don't exist separate from the everyday business of the nation. . . . we look for ourselves in the story, and determine how to make it right with creation. This kind of discourse is about the lessons, the teachings, meanings and the conduct that we must arrive at personally and collectively to make the story work for us and to work with the story. (Maracle, Memory Serves 204)

For Maracle, words have sacred power and are not to be wasted. "They represent the accumulated knowledge, cultural values, and vision of an entire people or peoples. . . Story is the most persuasive and sensible way to preserve the accumulated thoughts and values of a people" (Memory Serves, 161). Maracle and other Indigenous authors writing today use the power of their words to carry their own cultural values, generate strengths in their own communities, uphold old and new traditions, rather than continue to respond to settler colonialization and its ills.

So while resistance may be part of the conversation in discussion Indigenous literature, it certainly isn't the entire discussion. Some of the other R words I have woven into this article already are powerful threads in the conversation in Indigenous Studies: resilience, respect, reciprocal relationships, responsibility, and response-able reading are all words used by various authors, critics, teachers, students, elders from whom I learn.

But in thinking about resistance, I often turn back for guidance to the words from Acoma Pueblo poet Simon Ortiz's frequently cited and reprinted 1981 essay, "Towards a National Indian Literature: Cultural Authenticity in Nationalism," in which Ortiz refers to a culture of "resistance against forces that would destroy 
life. It is by affirmation of knowledge of source and place and spiritual return that resistance is realized" (11). This definition, written well before Maracle's Celia's Song, describes what I see happening in that novel. The characters are facing forces that would destroy life, but the affirmation of Stó:lō knowledge, the recognition of place, the grounding in the longhouse and the return to powerful, generative, generous ways of upholding traditions of being in relation are the realization of resistance.

Another related $\mathrm{R}$ word to underscore here is resurgence. For Simpson, in her book, Dancing on Our Turtle's Back, resurgence is a process that reclaims relationships with the land, language, and traditional knowledge in Indigenous communities. In "Re-envisioning Resurgence: Indigenous Pathways to Decolonization and Sustainable Self-Determination," Cherokee scholar Jeff Corntassel and Songhees ethnobotanist Cheryl Bryce use the term resurgence as they speak to the ways in which Indigenous peoples need to confront existing colonial institutions, structures, and policies that continuously attempt to displace them from homelands and relationships, asserting "Indigenous resurgence is about reconnecting with homelands, cultural practices, and communities, and is centered on reclaiming, restoring, and regenerating homeland relationships" (Corntassel and Bryce, "Practicing Sustainable Self-Determination" 153). Their definition of resurgence thus highlights additional $\mathrm{R}$ words: reconnecting, reclaiming, restoring and regenerating. In another co-authored Corntassel piece, Indigenous storytelling is directly connected to homelands and "to the cultural and political resurgence of Indigenous nations” (Corntassel, Chaw-win-is and T'lakwadzi 137).

Resurgence and resistance are sometimes linked together. For example, Métis scholar Adam Gaudry published a piece entitled "Researching the Resurgence: Insurgent Researchand Community Engaged Methodologies in 21st Century Academic Inquiry" in a book called Research as Resistance. For Gaudry, insurgent research is motivated by working in and with Indigenous communities, for communities, in collaborations that center the interests of the Indigenous communities, not the academic researchers. Insurgent research is then part of the broader movement of Indigenous resurgence and decolonization.

Even as I note that resurgence is a growing theoretical term in Indigenous Studies, I still see the core elements that connect back to what I find in Simon Ortiz's words about resistance-the connection to homelands, cultural practices, and communities, the return to place, to knowledge, to relationships (spiritual, political, and more). Simpson's concept of "generative refusal" (As we Have 35) may also be helpful in thinking about resistance because her term conceptualizes resistance as care for the kinship relationships that constitute Indigeneity. That resistance is not just a refusal of colonial domination but an embodiment of Indigenous ways and norms, being grounded in and mindful of those Indigenous ways of being and being in relation.

Terms change, but some core concepts and commitments are threads we can trace throughout the decades of writing and criticism in the field. But the words chosen are important, as award-winning Métis poet Marilyn Dumont often reminds 
us in her poems. Dumont is perhaps most well-known for her first book of poetry, $A$ Really Good Brown Girl, but I highlight here a poem, "nomenclature" from her 2007 collection that tongued belonging. Dumont writes of those who had their history ignored, and who see how "the history of settlers, in the settlers of history" rename all the rivers, lakes, mountains, plants and animals of the land. Her two columns points out the important differences in naming:

\author{
You say, Canada, \\ You say, grandmother, \\ You say, General Dumont, \\ You say, Rupert's Land, \\ You say, treason,
}

\author{
I say, Turtle Island \\ I say, Nokum, \\ I say, cousin, \\ I say, home, \\ I say, self-defense.
}

This poem highlights issues of language and who gets to draw the maps. Maps tell a story. Different peoples author that story, that map, differently. Maps imply a history with the land, relationships with topography and geology, but whose history and whose relationships are marked on that map and by whom? Who can find themselves on that map? Many of the contentious issues we see around the world today revolve around who has the right to be in which spaces, who is being asked to disavow their own maps, knowledges, and cultures, who feels that the authority and the stories of others are being superimposed on their own? Whose words, whose maps, and whose stories matter? As we deal with these difficult issues, powerful stories by Indigenous authors that center on the importance of respect, reciprocal relationships, responsibility, and reverence might serve as maps for us all.

\section{Richness}

Before ending this essay, I want to highlight one last R word: richness. The rich repertoire of Indigenous literature is full of what Justice refers to as "good stories," good because they are written by Indigenous people to "give shape, substance, and purpose to [their] existence and to help [them] understand [their] responsibilities to each other and to the rest of creation" (Why Indigenous Literatures Matter 2). These stories are good stories "not always happy, not always gentle, but good ones nonetheless because they tell the truths of our presences in the world today, in days past, and in days to come" (Why Indigenous Literatures Matter 2). Readers can find these "good stories" in different genres, from different nations, and in different languages. Justice himself is the author of a fantasy series called The Way of Thorn $\mathcal{E}$ Thunder and has reflected in interviews on the importance of telling "the kind of epic fantasy that I'd love to read - namely, a tale rooted in the lands, languages, and socio-political contexts of this hemisphere, not those of northern Europe" (Innsmouth Free Press interview). Tuscarora author and critic Alicia Elliot offers a 
quick review of some recent works of Indigenous horror in her brilliant essay for CBC Arts, "The rise of Indigenous horror: How a fictional genre is confronting a monstrous reality," in which she poses the pointed question, "What more is there to fear when you've already faced governments who have tried for centuries to wipe you out, who have used biological warfare and forced starvation to create apocalypse for your people?" Waubgeshig Rice's Moon of the Crusted Snow, Cherie Dimaline's The Marrow Thieves, and the poem "Canadian Horror Story" from Billy-Ray Belcourt's poetry collection, NDN Coping Mechanisms: Notes from the Field are all woven into an essay that reminds readers of the reason many turn to the horror genre, even in disturbing times: at least in the fictional works, the monsters stop. The richness in these and other narrative, poetic and dramatic genres showcase the continuing power and importance of Indigenous voices in this present time.

\section{References}

ANDERSON, Kim. (2001). A Recognition of Being: Reconstructing Native Womanhood. Canadian Scholars' Press.

BAKER, Maria Annharte (2013). AKA Inendagosekwe. CUE Books, 2013.

BEARD, Laura J. (2009). Acts of Narrative Resistance: Women's Autobiographical Writings in the Americas. University of Virginia Press.

BEARD, Laura J. (2018). “” This Story Needsa Witness": The Imbrication of Witnessing, Storytelling, and Resilience in Lee Maracle's Celia's Song." Studies in American Indian Literatures 30.3-4: 151-178.

BELCOURT, Billy-Ray. (2019).Ndn Coping Mechanisms: Notes From the Field. Toronto: Anansi.

BLAESER, Kimberly M. (1999). "Writing voices speaking: Native authors and an oral aesthetic." Talking on the Page: Editing Aboriginal Oral Texts. Eds. Laura J. Murray and Keren Rice. University of Toronto Press, 53-68.

CORNTASSEL, Jeff and Cheryl Bryce. (2012).”Re-envisioning resurgence: Indigenous pathways to decolonization and sustainable self-determination." Decolonization: Indigeneity, Education \& Society 1.1.

CORNTASSEL, Jeff. Chaw-win-is. T’lakwadzi. (2009). "Indigenous storytelling, truth-telling, and community approaches to reconciliation.” ESC: English Studies in Canada 35.1: 137-159. 
DIMALINE, Cherie. (2018). The Marrow Thieves. Toronto: Dancing Cat Books.

DUMONT, Marilyn. (1996). A Really Good Brown Girl. London, Ontario: Brick Books.

DUMONT, Marilyn. (2007). that tongued belonging. Kegedonce Press.

ELLIOT, Alicia. (2019). "The Rise of Indigenous Horror: How a Fictional Genre is Confronting a Monstrous Reality." CBC Arts. October 17, 2019. https://www.cbc. $\mathrm{ca} /$ arts/the-rise-of-indigenous-horror-how-a-fictional-genre-is-confronting-amonstrous-reality-1.5323428

GAUDRY, Adam. (2015). "Researching the Resurgence: Insurgent Research and Community Engaged Methodologies in 21st Century Academic Inquiry." Research as Resistance: 243-267.

JUSTICE, Daniel Heath. (2011). The Way of Thorn and Thunder: The Kynship Chronicles. University of New Mexico Press,

JUSTICE, Daniel Heath. (2018). Why Indigenous Literatures Matter. Wilfrid Laurier Press.

MARACLE, Lee. (2014). Celia's Song. Cormorant Books.

MARACLE, Lee. (2015). Memory Serves: Oratories. Edited by Smaro Kamboureli. NeWest Books.

MARACLE, Lee. (2014). “Lee Maracle’s Tale.” Quill E Quire. November. https:// quillandquire.com/authors/lee-maracles-tale/

ORTIZ, Simon J. (1981). “Towards a National Indian Literature: Cultural Authenticity in Nationalism.” MELUS, vol. 8, no. 2, p. 7. EBSCOhost, doi:10.2307/467143.

REDER, D. (2010). "Awina maga kiya (who is it that you really are)?: Cree and Métis Autobiographical Writing." Canadian Literature, (204), 131-134,165.

RICE, Waubgeshig. (2018).Moon of the Crusted Snow. Toronto, ON: ECW Press.

SIMPSON, Leanne Betasamosake. (2017). As We Have Always Done: Indigenous Freedom Through Radical Resistance. University of Minnesota Press.

SIMPSON, Leanne Betasamosake. (2011). Dancing On Our Turtle's Back: Stories of Nishnaabeg Re-creation, Resurgence and a New Emergence. Winnipeg: Arbeiter Ring Pub. 